\title{
Customers' Trust on E-Banking System in Bangladesh
}

\author{
Mohammad Shamsus Sadekin ${ }^{1}$, Shamima Nasrin Mukta ${ }^{1}$, Md. Abdul Hannan Shaikh ${ }^{2}$ \\ ${ }^{1}$ Department of Humanities, Chittagong University of Engineering \& Technology, Chittagong, Bangladesh \\ ${ }^{2}$ Department of Management, Islamic University, Kushtia, Bangladesh
}

Email address:

sadekinmba@yahoo.com (M. S. Sadekin), s.mukta91@gmail.com (S. N. Mukta), Hannanbiu@yahoo.com (Md. A. H. Shaikh)

\section{To cite this article:}

Mohammad Shamsus Sadekin, Shamima Nasrin Mukta, Md. Abdul Hannan Shaikh. Customers' Trust on E-Banking System in Bangladesh. International Journal of Economics, Finance and Management Sciences. Vol. 7, No. 6, 2019, pp. 178-186.

doi: 10.11648/j.ijefm.20190706.11

Received: October 16, 2019; Accepted: October 23, 2019; Published: October 30, 2019

\begin{abstract}
E-banking is the newest improvement in banking sector which is a latest dimension to banking dealings by permitting customers to perform financial transaction through the delivery channel. The study was designed to investigate practices, impact, security, problems and prospects of e-banking in Bangladesh which are directly related with the trust on electronic banking. To collect data for this study a set of questionnaire was developed with 44 questions which covered the above mentioned elements of e-banking in Bangladesh. Total 224 respondents are selected purposively from bankers and customers of whom 75 bankers and 149 are bank customers of sixteen randomly selected banks. Banks are classified into four categories like state owned commercial bank, domestic private commercial bank, foreign commercial bank and other specialized bank which activates in Bangladesh. Statistical software SPSS was used to analyze data. The result shows that customers trust depends basically on security measures, customers awareness, educational qualification, authentication of etransaction, e-service quality of banks, bankers behavior etc. Every step in the online banking activities is secured by one or more security mechanisms. Customer's awareness is one of the most important elements to build up trust on e-banking. Low educated people are afraid of doing e-banking operation. Problems or difficulties are directly related with customers trust. If customers trust is reduced if they face difficulties to do an e-transaction.
\end{abstract}

Keywords: E-banking, Problems, Security, Trust

\section{Introduction}

E-banking is a new banking system which has been added in last decade in Bangladesh. Till now majority Bangladeshi customers are not habituated in e-banking system. E-banking advancement of any country mostly depends on customers' trust on this system. Customers' trust in e-banking system of any bank is depend on some criteria like; service quality, security, speedy network customers' educational qualification etc. Customers' trust on e-banking system will be increased if e-service quality of any bank is better than traditional banking system due to customers' satisfaction. Customers' satisfaction on e-banking system is depends on service above mentioned terms of banking transactions. If Bangladeshi banks will fail to increase customers' trust on this banking transactions its future will be very dark. This research tried to find out trust of Bangladeshi customers on e-banking system. E-banking is the banking activities performed through the electronic means, i.e. using telecommunications network, web technology, computers, cellular phones and other electronic devices [1]. Now a day's due to emerging global economy, e-commerce, and e-business have increasingly become a necessary component of business strategy and a strong catalyst for economic development. The new information technology is becoming an important factor in the future development of financial services industry, and especially banking industry. As a third-world developing country, Bangladesh is far behind to reach the system [2]. Ebanking facilities not only make banking activities faster but also provide different online services like Internet Banking, ATM, POS, terminals which helps people to get banking facility in a faster way. Although e-banking swindle in large scale in the country and central bank of Bangladesh needs to take all the necessary measures to prevent it. This can be done through proper education on information technology and sufficient software \& hardware support [3]. Customers think that e-banking services were relatively good than 
manual system, but they not satisfied with the quality of services and bank personnel's' behavior to that extent. Ebanking serves several advantages to Bangladeshi banking sector, however, this study also observed that the customers of DBBL have not enough knowledge regarding e-banking which is rendering by banking sector in Bangladesh [5]. E-banking provides convenience and flexible advantages. It also provides transaction related benefits like easy transfer, speedy transaction, less cost and time saving [6]. Although e-banking concept is new in Bangladesh but its potentiality is high [7]. Users' perceived ease of use failed to predict the customers' intention to use online banking services [8]. The advancement of e-banking depends on customers trust on this system. Security status of ebanking and customers trust on it are directly related with one another. The development of the concept of electronic financial services, more commonly known as e-banking. At present, private \& public banks of Bangladesh have taken various steps in E-banking [9]. Consumers are attracted to e-banking technologies because of convenience, increasing ease of use, and in some instances cost savings [18].

\section{Methodology of the Study}

This study has been done based on primary data. Data has been collected from 16 selected banks in Bangladesh. To collect data for this study a set of questionnaire was developed with 44 questions which covered e-banking practice in Bangladesh, it security, problems and prospects. Total 224 respondents were selected purposively from bankers and customers. Out of the respondents 75 are bankers and 149 are bank customers of sixteen randomly selected banks. Banks are classified into four categories like state owned commercial bank, domestic private commercial bank, foreign commercial bank and other specialized bank which activates in Bangladesh. Statistical software SPSS was used to analyze data. Sample were selected from State Owned commercial banks, domestic private commercial banks and foreign commercial banks in Bangladesh and bank customers were selected from branches in different territory like Dhaka, Chittagong, Rajshahi, Khulna and Rangpor division. Responds were collected from university, college and school teachers and students, businessmen and other professionals from private and public sectors. Information was collected from the branch of rural areas and different towns Bangladesh. A set of questionnaire was designed and was sent to the respondents through e-mail. Secondary data was also used for this study Secondary data has been collected from the website of different banks. The collected information' have been analyzed by SPSS.

\section{Literature Review}

A number of research studies have been conducted on adoption, practice, impact and securities of e-banking in home and abroad. Some of the relevant studies reviewed and presented below in accordance to year (present to previous) of publication:
Trust on e-banking depends on some factors like; security system, service quality, simplicity of e-transactions, internet facilities and its speed quality, and prospects of e-banking system etc. The following research works have been concentrated on these terms of e-banking. One of the electronic services which are gaining more popularity and attention is ebanking. The consideration given to the e-banking by the current traditional banking customers may be due to the changes in the banking consumers' lifestyle, and this lifestyle have become compatible to the new way of conducting banking services online. Trust and security are among the central factors that influence banking customers' acceptance of the service [8]. Demographic factors impact significantly internet banking behavior, specifically, occupation and instruction. the perceived convenience, perceived risk, perceived security and prior internet knowledge all have significant effects on behavioral intention to use online banking among 'early adopters', convenience was a more important indicator of intentions to adopt internet banking. Risk, security and prior internet knowledge is also an important factor influencing customers adopting internet banking after convenience. Among demographic variables, further significant influences have been found for instruction and occupation [10]. Information technology is becoming an important factor in the future development of financial services industry, especially the banking industry. The banking sector is based on sharing of information, which itself heavily relies on information and communication technology (ICT) in order to acquire, analyze and deliver data to all relevant users. The ICT is crucial not only for information analysis, but also enables the banking sector to differentiate its offer from competitors and thereby make it a market leader. In this context, banking sector are obliged to continuously innovate and update their marketing strategies in order to closely meet the demands and the requirements of the individual customers. It also provides safe and confidential services which best suit customers' needs. The customer wants more flexibility without paying more, and his demands are clear: Make transactions wherever, whenever, and however he wants [9]. Electronic banking offers numerous benefits to SMEs. SMEs can check account balances, transfer money, pay bills, collect receivables and ultimately reduce transaction costs and establish greater control over bank accounts [11]. Bank could increase internet banking adoption by making their customers awareness about the usefulness of the service. The variable perceived usefulness has a positive influence on internet banking use, therefore internet banking acceptance would increase when customers find it more usefulness. Bank should plan their marketing campaigns taking into consideration this factor [12]. Mainly four factors are significant with respect to the e-banking practices. Privacy \& convenience, content \& website layout, speed of delivery, and accessibility are the critical factors influencing the e-banking practices [13]. The development of Internet Banking (I-Banking) requires a new recognition of customers' values for building long-term organization-customer relationships in the E-era. Value was the most critical factor impacting customers' trust in I-Banking, compared with two other important factors; communication and opportunistic 
behavior control. The shared value was the most critical factor impacting customers' trust in I-Banking. As regarding improving loyalty among I-Bank customers, findings suggest that IBanking needs to take satisfaction, trust, brand reputation and switching cost seriously, especially satisfaction, because it is the most important factor that influences customers' loyalty [14]. The squire of correlation coefficient of number of ATM, recoveries from clients, number of branches, income from IT, card expenses, cash carrying charge, depreciation on computer equipment and software, other operating expenses, net income and EPS is more than 0.5. It indicates the prospect of e-banking in Bangladesh is very bright [3]. The factor that is necessary for trust building in all the examined countries differs: In Lithuania, information and the bank, in Latvia, the website, and in Estonia, the bank. According to the experts, the most powerful factor in the trust-building process in Lithuania and Latvia is the ebanking system while in Estonia, the website. The research has the following limitations: The online survey of individual customers (however, internet banking relates to internet users, so this limitation is not essential); the analysis of only the positively affecting criteria of the trust-building process; only experts assessed the sub-factors [16]. Ease of use and usefulness; have been considered to be fundamental in determining the acceptance of various IS in the past decades. These beliefs may not, however, fully explain the users' behavior in an emerging environment such as Internet banking. Trust is another belief that has an impact on the acceptance of Internet banking. We collected 845 cases on the Web to survey users' behavior towards Internet banks. The results of statistical analyses using structural equation modeling indicate that trust has a significant impact on the acceptance of Internet banking [17]. Trust on ebanking of any countries somewhat depends on prospects of ebanking of that countries.

\section{Analysis and Findings}

Followings are the presentation of the result and analysis of data collected for the study. The study has been conducted mainly based on primary data. Secondary data has also been used for this work. Total 224 respondents are selected from bankers and customers. Out of 224 respondents 75 are bankers and 149 are bank customers of sixteen randomly selected banks. Bankers provide their opinion as an account holder of the related bank. Data for this study has been collected from 16 banks. Out of 16; 03 banks are state owned commercial banks (Sonali Bank Ltd., Agroni Bank Ltd and Rupali Bank Ltd.), 08 domestic private commercial banks ( Islami Bank Bangladesh Ltd., Datch-Bangla Bank Ltd., Eastern Bank Ltd., BRAC Bank Ltd., First Security Islami Bank Ltd. Al-Arafah Islami Bank Limited, Social Islami Bank Ltd. Bank Asia Ltd.) 03 foreign commercial banks (Standard Chartered Bank Ltd., Citi Bank Ltd, Bank Alfalah) and 02 specialized banks ( Grameen Bank, BASIC Bank) have been selected purposively. Respondents have been selected from various branches of Dhaka, Chittagong, Rajshahi, Rangpur and Khulna Division and 224 Samples were purposively selected from different categories of bank customers like male and female, banker and bank customers, highly educated and low educated customers, different types of account holders, different professionals (service holder, teacher and business man, journalist and self employed person). Bankers have been selected as an account holder of related bank. For this study a set of questionnaire has been used to collect data which carried 44 questions. The questionnaire has covered e-banking practices in Bangladesh and its impact on customers, it security, problems and prospects which are closely related with customers trust of ebanking. Out of 44 questions 11 questions are related with ebanking practice, 09 questions are related with the impact, 12 questions are related with the security and remaining questions are related with problems and prospects of e-banking in Bangladesh. Secondary data has been collected from banks' web sites, different articles and news papers. Statistical software SPSS was used to analyze the data collected from the respondents.

Table 1. Type of Accounts and Educational Qualification of the Respondents.

\begin{tabular}{|c|c|c|c|c|c|c|c|}
\hline \multirow[b]{2}{*}{ Education } & \multicolumn{6}{|c|}{ Type of Online Account } & \multirow{2}{*}{$\begin{array}{l}\text { Total } \\
\text { No. (\%) }\end{array}$} \\
\hline & $\begin{array}{l}\text { Mobile Banking } \\
\text { No. }(\%)\end{array}$ & $\begin{array}{l}\text { Credit Card } \\
\text { Account No. (\%) }\end{array}$ & $\begin{array}{l}\text { ATM account } \\
\text { No. }(\%)\end{array}$ & $\begin{array}{l}\text { Internet Banking } \\
\text { No. }(\%)\end{array}$ & $\begin{array}{l}\text { Other } \\
\text { No. }(\%)\end{array}$ & $\begin{array}{l}\text { N/A } \\
\text { No. (\%) }\end{array}$ & \\
\hline SSC & $0(0)$ & $0(0)$ & $4(50)$ & $0(0)$ & $0(0)$ & $4(50)$ & $7(3)$ \\
\hline Bachelor Degree & $26(24)$ & $9(9)$ & $28(26)$ & $13(12)$ & $0(0)$ & $32(29)$ & $108(48)$ \\
\hline Master Degree & $7(7)$ & $2(2)$ & $52(45)$ & $11(11)$ & $9(9)$ & $28(26)$ & $108(48)$ \\
\hline $\mathrm{Ph} . \mathrm{D}$ & $2(1)$ & $0(0)$ & $0(0)$ & $0(0)$ & $0(0)$ & $0(0)$ & $1(1)$ \\
\hline Total & $35(16)$ & $11(5)$ & $82(35)$ & $24(11)$ & $9(4)$ & $63(28)$ & $224(100)$ \\
\hline
\end{tabular}

Table 1 shows that majority of the respondents (48\%) use online accounts are Bachelor Degree Holder. The next highest numbers of respondents use online accounts are Master Degree Holder (48\%) and Bachelor Degree Holder
(48\%). Lowest number of respondents $(01 \%)$ is Ph.D. holders. Among the online accounts ATM account is used by majority $(35 \%)$ of the respondents.

Table 2. E-Service Quality of Different Types of Bank.

\begin{tabular}{|c|c|c|c|c|c|}
\hline \multirow{2}{*}{ Types of Bank } & \multicolumn{5}{|c|}{ E-Service Quality of Different Types of Bank in Bangladesh } \\
\hline & Not Good No. (\%) & Satisfactory No. (\%) & Very Good No. (\%) & Excellent No. (\%) & Do not Know No. (\%) \\
\hline State Owned Commercial banks & $23(10.27)$ & $71(31.70)$ & $65(29)$ & $62(27.68)$ & $3(1.35)$ \\
\hline Domestic Private Commercial Banks & $18(8.04)$ & $30(13.39)$ & $83(37.05)$ & $92(41.07)$ & $1(0.45)$ \\
\hline Foreign Commercial Banks & $02(0.89)$ & $15(6.70)$ & $65(29.02)$ & $118(52.68)$ & $24(10.71 \%)$ \\
\hline
\end{tabular}


Table 2 shows that the highest percent of respondents $(52.68 \%)$ mentioned e-service quality of foreign commercial banks and $41.07 \%$ of domestic private commercial banks are excellent. Out of the respondents' majority (31.70\%) mentioned that e-service quality of state owned commercial banks are not good.

Table 3. Security of E-Transaction in Different Types of Banks in Bangladesh.

\begin{tabular}{|c|c|c|c|c|c|}
\hline Types of Bank & $\begin{array}{l}\text { Don't know } \\
\text { No. }(\%) \\
\end{array}$ & $\begin{array}{l}\text { Not secured at all } \\
\text { No. }(\%) \\
\end{array}$ & $\begin{array}{l}\text { Not enough secured } \\
\text { No. }(\%)\end{array}$ & $\begin{array}{l}\text { Sufficient Secured } \\
\text { No. }(\%)\end{array}$ & $\begin{array}{l}\text { Highly Secured } \\
\text { No. }(\%)\end{array}$ \\
\hline State Owned Commercial Bank & $13(5.80)$ & $0(0)$ & $53(23.66)$ & $86(38.39)$ & $72(32.14)$ \\
\hline Domestic Private Commercial Bank & $26(11.61)$ & $21(9.38)$ & $78(34.82)$ & $66(29.46)$ & $33(14.73)$ \\
\hline
\end{tabular}

It is evident from the table 3 that among the respondents $38.39 \%$ mentioned that e-banking security of state owned commercial bank is sufficient secured, and $34.82 \%$ respondents mentioned that e-banking service of domestic private commercial banks are not enough secured. According to $71.88 \%$ respondents' e-banking function of foreign commercial banks are highly secured.

Table 4. Educational Qualification and Trust on E-Banking.

\begin{tabular}{|c|c|c|c|c|c|c|}
\hline \multirow{2}{*}{ Educational Qualification } & \multicolumn{5}{|c|}{ Trust on E-Banking } & \multirow{2}{*}{$\begin{array}{c}\text { Total } \\
\text { Total }\end{array}$} \\
\hline & Less Than $25 \%$ & Less Than $50 \%$ & Less Than $75 \%$ & Less Than $100 \%$ & $100 \%$ Trust & \\
\hline SSC & $04(50 \%)$ & $04(50 \%)$ & $00(0 \%)$ & $00(0 \%)$ & $00(0 \%)$ & 08 \\
\hline Bachelor Degree & $17(7.59 \%)$ & $093.75 \%$ & $24(11.16 \%)$ & $34(15.18 \%)$ & $23(10 \%)$ & 107 \\
\hline Masters Degree & $9(4.02 \%)$ & $17(7.59 \%)$ & $25(11.61 \%)$ & $34(15.18 \%)$ & $22(9.82 \%$ & 107 \\
\hline Doctorate Degree & $00(0 \%)$ & $00(0 \%)$ & $00(0 \%)$ & $00(0 \%)$ & $02(100 \%)$ & 02 \\
\hline Total & & & & & & 224 \\
\hline
\end{tabular}

Table shows that $100 \% \mathrm{PhD}$ degree holders have $100 \%$ trust on e-banking transaction and $100 \%$ SSC degree holders have less than $50 \%$ trust on e-banking transactions in Bangladesh.

Table 5. Satisfaction of Customer and Their Trust on E-Banking.

\begin{tabular}{|c|c|c|c|c|c|}
\hline \multirow{2}{*}{ Satisfaction Level } & \multicolumn{4}{|c|}{ Trust on E-Banking } & \multirow{2}{*}{ Total } \\
\hline & $0 \%-25 \%$ Trust & $25 \%-50 \%$ Trust & $50 \%-75 \%$ Trust & $75 \%-100 \%$ Trust & \\
\hline Fully Satisfied & $13(30.23 \%)$ & $4(9.30 \%)$ & $9(20.93 \%)$ & $17(39.54 \%)$ & $43(19.20 \%)$ \\
\hline Highly Satisfied & $22(30.06 \%)$ & $11(18.03 \%)$ & $17(27.87 \%)$ & $11(18.03 \%)$ & $61(27.23 \%)$ \\
\hline Sufficient Satisfied & $6(13.33 \%)$ & $15(33.33 \%)$ & $17(37.78 \%)$ & $7(15.56 \%)$ & $45(20.08 \%)$ \\
\hline Not Enough Satisfied & $11(27.5 \%)$ & $9(22.5 \%)$ & $11(27.5 \%)$ & $9(22.5 \%)$ & $40(17.86 \%)$ \\
\hline Dissatisfied & $0(00 \%)$ & $6(37.5 \%)$ & $6(37.5 \%)$ & $4(25 \%)$ & $16(7.14 \%)$ \\
\hline Highly Dissatisfied & $1(5.26 \%)$ & $8(42.61 \%)$ & $6(31.58 \%)$ & $4(20.55 \%)$ & $19(8.49 \%)$ \\
\hline
\end{tabular}

Table No. 5 shows that $19.20 \%$ respondents are fully satisfied on e-banking service and their trust $(39.54 \%)$ is comparatively higher than others. Out of the respondents
$8.49 \%$ are highly dissatisfied on e-banking service and majority $(42.61 \%)$ of them have minimum $(25 \%-50 \%)$ trust on e-banking.

Table 6. E-Services Provided by the Banks in Bangladesh.

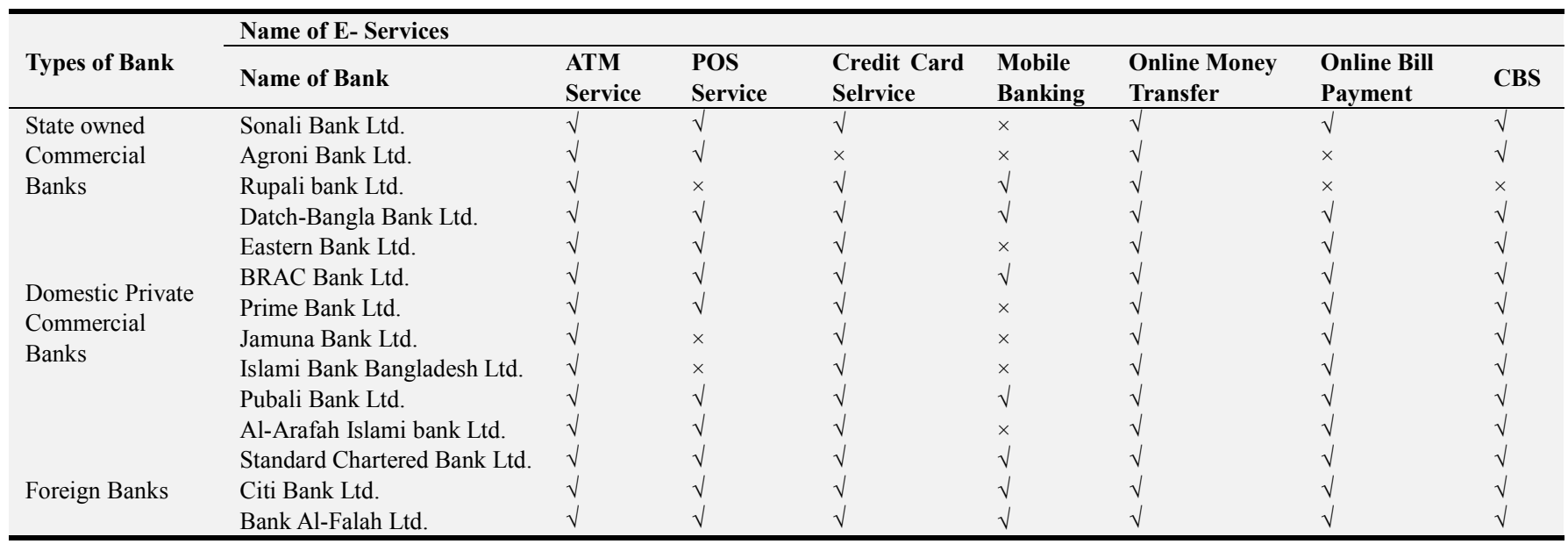

Table 6 shows that almost all banks provide e-banking services but foreign commercial banks are in leading position. 
Table 7. Special E-Services Offered by the Bank.

\begin{tabular}{|c|c|c|}
\hline Types of Bank & Name Of Bank & Special Services \\
\hline \multirow{6}{*}{$\begin{array}{l}\text { Domestic Private } \\
\text { Commercial Banks }\end{array}$} & $\begin{array}{l}\text { Datch-Bangla } \\
\text { Bank Ltd. }\end{array}$ & $\begin{array}{l}\text { Electronic Banking: Dutch-Bangla Bank is the first bank in Bangladesh to be fully automated and introduce } \\
\text { Electronic Banking. DBBL client now has unrivaled access to banking from any DBBL branch, ATM and POS. } \\
\text { All of these services are free-of-charge and are surprisingly affordable for everyone. } \\
\text { Mobile Banking: DBBL pioneered Mobile Banking in Bangladesh. It was the first bank to offer banking facilities } \\
\text { through a wide range of mobile phones. SMS (Short Messaging System) is an extremely unsecure method to do } \\
\text { mobile banking. DBBL recommends you use a HTML browser found on many phones to access internet banking } \\
\text { facilities. To make the most unsecure scenario, DBBL issues a mobile PIN number which is different from the } \\
\text { DBBL pin number for mobile transactions. }\end{array}$ \\
\hline & \multirow{3}{*}{$\begin{array}{l}\text { Eastern Bank Ltd. } \\
\text { Islami Bank } \\
\text { Bangladesh Ltd. } \\
\text { Al-Arafah } \\
\text { Islami bank Ltd. } \\
\text { Pubali Bank Ltd. }\end{array}$} & EBL Fast Cash, EBL Cash Deposit Machine, EBL Kotipoti Scheme, EBL Power savings \\
\hline & & $\begin{array}{l}\text { ATM services, Internet Banking, Payment Gateway, Mobile Banking, Consumer Banking Corporate Banking } \\
\text { Investment Banking }\end{array}$ \\
\hline & & Agent Banking, Evening Banking, Ababil Software, \\
\hline & $\begin{array}{l}\text { Pubali Bank Ltd. } \\
\text { BRAC Bank Ltd }\end{array}$ & $\begin{array}{l}\text { PIBS, Evening banking in some branches. Charge free online banking } \\
\text { BRAC Bank Mobile Banking, B-cash, Internet Banking, 24-Hours Call Center, SMS Banking, Mobile Top-up, evening } \\
\text { banking, i-wallet service discounted, Important security message, Phishing Alert, Internet Banking User Manual. } \\
\text { One Stop Utility Services Scheme: To pay Electricity Bills, Cash deposit in his/her account at any branch of the }\end{array}$ \\
\hline & Prime Bank Ltd. & $\begin{array}{l}\text { Bank irrespective of location. Cash deposit in other's account at any branch of the Bank irrespective of location. } \\
\text { Transfer of money from his/her account with any branch of the Bank. } \\
\text { Non-Resident Bangladeshi (NRB) Banking: AB bank facilities offered to NRBs Opening of Foreign Currency }\end{array}$ \\
\hline \multirow{3}{*}{ Types of Bank } & AB Bank Ltd. & $\begin{array}{l}\mathrm{A} / \mathrm{C} \text { : We open Foreign Currency Account in USD/GBP/EUR/JPY for NRBs. Foreign Currency can be remitted by } \\
\text { the Nationals of Bangladesh living Abroad earned by them as wage earners or from other sources. The deposit } \\
\text { amount can also be used for remittance to other. }\end{array}$ \\
\hline & \multirow[t]{2}{*}{ Name Of Bank } & Special Services \\
\hline & & $\begin{array}{l}\text { Employee Banking: Employee Banking proposition not only offers you a salary account but also comes with a perfect } \\
\text { value pack of Credit Card and Personal Loan. Other accounts are residents foreign currency deposit account and non- } \\
\text { resident foreign currency deposit account, Mobile baking, School Banking, Priority Banking. }\end{array}$ \\
\hline \multirow{5}{*}{$\begin{array}{l}\text { Foreign } \\
\text { Commercial Bank }\end{array}$} & $\begin{array}{l}\text { Standard } \\
\text { Chartered } \\
\text { Bank Ltd. }\end{array}$ & $\begin{array}{l}\text { Priority Banking As customers' wealth grows, so do your needs and aspirations. Whether you are looking to invest, } \\
\text { protect your wealth, make cash transactions, or buy or sell property, our holistic wealth management services have it } \\
\text { covered. As a Priority Banking client, you get a dedicated relationship manager, supported by our } 24 \text {-hour Priority } \\
\text { Contact Centre. We recognize your status globally, so you can draw on our pool of experts, network and strong } \\
\text { capabilities across our markets. You can count on us for your global banking needs, because your priorities are ours too. }\end{array}$ \\
\hline & \multirow[b]{4}{*}{ Citi Bank Ltd. } & i. Citi Bank led the first-ever global bond for Banglalink Digital Communications Ltd. \\
\hline & & ii. Citi Bank arranged the largest IPO in Bangladesh for Grameenphone Ltd. \\
\hline & & $\begin{array}{l}\text { iii. Citi Bank is the first bank to launch online transaction banking solution in the country in 2003-CitiDirect } \\
\text { iv. Citi Bank is the first bank to launch Direct Debit Program in } 2012\end{array}$ \\
\hline & & $\begin{array}{l}\text { v. Citi Bank is the first bank to organize Electronic Payment Road shows across the country in } 2014 \text { in } \\
\text { collaboration with Central Bank }\end{array}$ \\
\hline \multirow[b]{3}{*}{ Types of Bank } & & vi. Citi Bank Bangladesh is the only bank with E-Collect/Virtual Account solutions \\
\hline & Name of Bank & $\begin{array}{l}\text { vii.Only bank capable of providing real time MIS against incoming Electronic Fund Transfers. } \\
\text { Special Services } \\
\text { Al-falah Quick Finance: Al-falah Quick Finance is a personal loan against National Saving Certificates, Prize }\end{array}$ \\
\hline & Bank Al-falah & $\begin{array}{l}\text { Bonds, Al-falah GHP Principal Protected Fund \& PKR/FCY deposit for meeting personal, family and household } \\
\text { needs. It is one year revolving limit with quarterly mark-up payments. The amount of financing under AQF ranges } \\
\text { from Rs. } 50,000 \text { to } 2.5 \text { Crore. AQF shall not exceed } 90 \% \text { of the encashment value of the security offered. In case } \\
\text { of financing against Foreign Currency Deposit the maximum financing should not exceed } 85 \% \text { of the deposit } \\
\text { encashment value. In case of Al-falah GHP Principal Protected Fund taken as a security the financing approved } \\
\text { under AQF shall not exceed } 70 \% \text { of the face value of units held by the borrower. }\end{array}$ \\
\hline
\end{tabular}

Table 8. Suggestion of Respondents to Build up Trust on E-Banking in Bangladesh.

\begin{tabular}{|c|c|c|c|c|c|}
\hline & Increase E-Banking security & $\begin{array}{l}\text { Provide More E- } \\
\text { Banking Services }\end{array}$ & $\begin{array}{l}\text { Improve E- } \\
\text { Service Quality }\end{array}$ & $\begin{array}{l}\text { Using Secured } \\
\text { Password }\end{array}$ & $\begin{array}{l}\text { Avoid E-mail } \\
\text { Notification }\end{array}$ \\
\hline \multirow{7}{*}{$\begin{array}{l}\text { Number of } \\
\text { Respondents }\end{array}$} & $95(42.41 \%)$ & $26(11.61 \%)$ & $170(75.89 \%)$ & $77(34.37 \%)$ & $17(7.59 \%)$ \\
\hline & Increase E-Banking Practice & $\begin{array}{l}\text { Authentication of Cash } \\
\text { Withdrawals }\end{array}$ & $\begin{array}{l}\text { Continuous Power } \\
\text { Supply }\end{array}$ & $\begin{array}{l}\text { Close Circuit } \\
\text { Camera }\end{array}$ & Using Digital Signature \\
\hline & $41(18.30 \%)$ & $22(9.82 \%)$ & $75(33.48 \%)$ & $92(41.07 \%)$ & $27(12.05 \%)$ \\
\hline & Increase Speed Quality of & Infrastructural & \multirow{2}{*}{ Using Finger Print } & Avoid Share & Using One-Time \\
\hline & Internet Service & Development & & Password & Password \\
\hline & $\begin{array}{l}\text { Resist Hacker's Hidden } \\
\text { Camera }\end{array}$ & $\begin{array}{l}\text { Develop Integrated } \\
\text { Software }\end{array}$ & Formulate Policy & Social Security & Create Awareness \\
\hline & $11(4.91 \%)$ & $31(13.84 \%)$ & $09(04.02 \%)$ & $55(24.55 \%)$ & $89(39.73 \%)$ \\
\hline
\end{tabular}


Table No. 6 shows that to increase trust on e-banking $75.89 \%$ respondents state the needs to increase e-service quality, $44.64 \%$ mentioned the necessity of high speedy internet, $42.41 \%$ respondents gives suggestion to increase ebanking security, $39.73 \%$ respondents think to create awareness to build up trust on e-banking, $34.37 \%$ thinks bankers should use secured password, take initiative to increase its e-banking service in all of their branches. Some banks are providing e-banking services in limited scale. $11.61 \%$ respondents think that banks should provide more ebanking services.

\section{From the Analysis of Data the Following Major Findings Were Obtained}

i. It is obtained from Table 1 that the higher educated account holders are more interested in e-banking systems.

ii. Table 2 shows that e-service quality domestic private commercial banks and foreign commercial banks are comparatively better than state owned commercial banks and specialized banks in Bangladesh.

iii. It is gained from Table 3 that security of foreign commercial banks and state owned commercial banks is better than domestic private commercial banks.

iv. Table 4 express that trust on e-banking system is closely related with educational qualification of account holders'.

v. It is gained from Table 5 that customers trust depend customers' satisfaction on e-service quality and others like as behavior of bankers, helping mentality, internal environment of banks etc.

vi. Table 6 shows that all banks provide e-banking service but foreign commercial banks covers all the services of e-banking system.

vii.It is attained from Table 7 that domestic private commercial banks and foreign commercial bank provide some special service to their customers.

\section{Necessary Steps to Enhance Customers Trust on E-Banking in Bangladesh}

On the basis of respondent's comments, expert's opinions, and observations \& judgment of the researcher the following requirements are developed to build up trust on e-banking in Bangladesh:

a. Increasing E-Banking Practices: As state owned commercial banks are in backward position in e-banking practices; so this type of banks should take initiative to increase its e-banking service in all of their branches. Banks which are not providing e-banking services till now should start immediately. b. Providing More E-Banking Services: Some banks are providing e-banking services in limited scale. These banks should increase their online banking services i.e. should add more and more new e-banking services to their business. Domestic private commercial banks and foreign commercial banks should introduce those services which are available in developed countries in the world but not in Bangladesh.

c. Improving the Quality of E-Banking Services: Banks operating in Bangladesh should improve their e-banking service quality. As e-service quality of state owned commercial banks are not good, so this type of banks should be more conscious regarding service e-banking quality.

d. Removing Insecurities of E-Banking in Bangladesh: In Bangladesh the security of e-banking is not so good. Banks should be sincere on security issues of e-banking and remove all the insecurities of e-banking in relation to social, software and other security.

e. Securing Password: Bankers should encourage customers to use highly secured passwords. Strong passwords are mixed password which are more secured and difficult to hack.

f. Avoiding Sharing Password: Bank will provide the message to it's customers not to share password with any person. They will inform the customers about the bad impact of sharing password.

g. Avoiding E-Mail Notification: Banks should not use email notifications to request confirmation of personal information or to direct downloading of attachments. Hackers may find out the confidential information from e-mail and hack the account and manipulate.

h. Using One Time Passwords (OTP): One-time passwords (OTPs) are used only once. This type of password may be used by the users to protect cyber-crime in banking sector. A card will keep many passwords. When any password is used that password cannot be used again. Developed country has already introduced but till Bangladesh doesn't implement this software for better e-banking security. It will make e-banking activities more secured.

(i). Using Finger Print: Finger print may be used instead of digit or letter type password. It will not be possible for any hacker to collect the finger print of account holder. So by using finger print cybercrime in banking sector can be minimized.

(ii). Authenticating Cash Withdrawals: Bank should make the arrangement to authenticate cash withdrawals from ATM booth. When any customer insert card to withdraw money ATM booth bank's server will seek confirmation through account holder's cell phone. If account holder confirms then the transaction will take place and cash will be delivered. Otherwise cash will not deliver by the ATM booth. If any unexpected person tries to make any transaction, account holder will inform the bank to take action against hacking.

(iii). Ensuring Continuous Power Supply: For the operation of e-banking continuous power is a must. It can be made possible by generating power by own 
generator. Bank will provide generator to each branch and ATM booth.

(iv). Ensuring Close Circuit Camera: Banks should ensure close circuit camera in every branch and ATM. In addition, ATM boots stuff must request face covered man or women to open face in ATM booth to authenticate the user.

(v). Resisting Hacker's Hidden Camera: Hackers may set up any hidden-camera in side of ATM Booths to collect password of account holders. Then they will use this for hacking. So ATM booths should be careful to avoid these types of crime.

(vi). Reducing the Dependence of Customer on Bankers: To reduce the dependence of customer on banker in the lowest level open discussion programs, workshops or seminar may be arranged by the bank for e-banking customers and bankers to increase knowledge and awareness about e-banking activities.

(vii).Using Digital Signature: In this process, bank should arrange digital signature of the customer and ensure using it. So that signer cannot forge later and nobody can modify the message while in transit. To ensure authenticity, receiver can verify the signature and understand that the message really comes from sender Hash algorithm and asymmetric encryption is used to perform this operation.

(viii). Developing Integrated E-Banking Software: Banks should take initiatives to develop integrated ebanking software. Preference should be given by the bank authority to use local software over foreign software. Common gateway is required so that interbank transactions can be feasible. In this regard banks can negotiate with central bank.

(ix). Increasing Speed Quality of Internet Service: Banks are required to develop personal network to increase the speed quality of internet services and to facilitate their customers.

(x). Changing Attitude: Bankers are suggested to take initiative to change the attitude of customers in favor of e-banking. Customer's attitude is very important matter for various application of e-banking. Bank may increase publicity, offer free services for the short period and take other steps.

(xi). Developing Infrastructure: E-banking is growing fast in Bangladesh. But current infrastructure is not sufficient to provide best quality of e-service. As same as technological infrastructural development is also required to provide best quality of e-services. So they are suggested to develop necessary e-banking infrastructure.

Bank Customers Should Take the Following Steps

(i). Using Protection Password

Customers should use protection password in their files of important information, so that nobody can get access to those informations. They should also store the information on a CD that can be kept locked in a secure location.

(ii). Securing Online Shopping
Customer should select incepted and secured ordering site. For that they should look for two critical things on the ordering page before placing any online orders: (1) a lock icon in the bottom-left or top-right corner, which indicates that the site uses encryption when transferring your personal information and (2) the letters "https" instead of just "http" in the URL, which also indicates that the ordering site is secure.

(iii). Using Antivirus

Most viruses today are introduced into computers via internet downloads and e-mail. Customers should use reputed anti-virus software and keep it updated. They should run scans periodically and look for tell-tale signs of potential infection such as general slowness or messages indicating unavailability of your financial website when trying to log-in. They should remember that anti-virus protection is only as good as last update.

(iv).Storing Credit Card Information on a Website

While this may be more convenient but it is much less secured. Customers should use one credit card exclusively for online shopping. In case of an old computer the hard drive should be erased completely discarding or selling. A tech-savvy thief can recover even deleted information.

(v). Choosing User Name and Password

Customers should choose user name and password wisely. A combination of letters, numbers and special characters are to be used and password is to be changed periodically. Obvious words or dates like a nickname or your birth date should not be used. Customers should try to use mixed (number, letter, symbol) password as e-banking password. Such as (e.g., a5n€ $\mathrm{k}^{*} \mathrm{p} 7$ ). This type of password is difficult to hack and more secured.

(vi).Avoiding Sharing Personal Information

Account holders should not share personal information via e-mail. Because the hackers can easily hack e-mail account. Normally people use easy password and user ID for e-mail address and they do not keep too much privacy of e-mail ID or password.

(vii). Changing Password

To increase online security account holders are requested not to use the same password for a long time. Everyone should change his e-banking password at least within one month. They will not use same password for online banking that is already used for another purpose.

(viii). Logging Out from Bank Site

It is suggested to log out online banking session and restart the personal computer when the transaction is completed.

(ix). Selecting Secured ATM Booths

Account holder should always try to withdraw money from any secured ATM booth. All ATM booths of Bangladeshi banks are not placed in same secured area.

(x). Avoiding Public Computer

Customers should not use public computer for online banking activities. Suddenly electricity may disturb and connection will discontinue for some time and the user will be unable to log out from his account. Later on anybody can enter into that account and manipulate that.

(xi).Monitoring Account Regularly 
It will help the account holder to make the account secured for long run. If the account holder monitors his account regularly he will be informed about any dis-agreement of balance within short time.

\section{Recommendations for Policy Makers}

On the basis findings of the study, observations of the researcher and opinion of the resources persons the following recommendations are made for the policy makers:

(i). Formulating Policy

Government should formulate policy to encourage and facilitate e-banking practice in Bangladesh.

(ii). Social Security

Government have to ensure such social security that customers will not feel any sort of insecurity to withdraw and carry money from ATM booths. In this regard, steps can be taken to make law enforcing agencies free, fair, and more active.

(iii). Creating Awareness

To increase the awareness about e-banking government can facilitate publicity in print and electronic media about ebanking practice and its security.

(iv).Developing Secured Software

Government can provide incentives to produce highly secured software. Central bank will monitor the security level of e-banking of Bangladeshi banks.

(v). Ensuring Uninterrupted Power Supply

Government should ensure continuous power supply in every branches and ATM booths of each and every bank. Steps should be taken to generate more power considering the demand of the country.

(vi).Developing Infrastructure of the Country

Measures should be taken to develop overall infrastructure of the country that will support e-banking practices.

(vii). Providing Speedy Internet Service

Internet service in Bangladesh is slow. It is a barrier to expand e-banking. Steps should be taken to make internet service speedy.

(viii). Providing Low Cost Equipment

Government should reduce tax on those equipment' which are related with e-banking. As a result equipment will be cheaper in the market.

(ix).Monitoring

Government through central bank increase monitoring on e-banking so that its practices can be smooth and expanding.

(x). Promulgating Legal Provisions

Government should promulgate and apply special laws favoring e-banking practices and controlling frauds and malpractices.

\section{Conclusion}

Almost all Bangladeshi banks offer e-banking services. State owned commercial banks are in backward position and specialized banks are in early stage of e-banking. Quality of ebanking services in Bangladesh is not good. E-banking transactions in Bangladesh are not highly secured. Bangladeshi users have lack of awareness about e-banking and its security and mentionable quantity of users don't use highly secured password. Many of them share their e-banking password with others like spouse, parent, children, brothers, sisters and friends, which is very risky in the point of security. Many users have no personal computer and internet connection. They use outside computer for e-banking functions. Customers feel insecurity from hijacker to withdraw and deposit money from ATM booths. All the ATM booths of Bangladeshi banks are not located in safe position. Bangladesh does not have sufficient infrastructure for e-banking. Power crisis is a barrier for e-banking promotion and almost all the banks fail to provide generator to their all branches and ATM booths to produce power for emergency time. Internet connection in Bangladesh is not sufficient speedy. All the banks don't have highly secured software for etransactions. Some banks used different software in different time which is painful for users. Out of these limitations ebanking has great effect on our banking industry. E-banking required minimum man power than traditional banking and reduces risk of carrying cash. Cards are provided to customer who reduces huge documents for banking function. E-banking made shopping easy by providing credit and debit card. Cards are used for withdrawing cash from ATM booths and for shopping products from the market. Both bankers and customers in Bangladesh can be benefited immensely by adopting appropriate measures in the light of the present findings for enhancing practice and security of e-banking which are extremely important for the development of customers trust on e-banking in Bangladesh.

\section{References}

[1] Al-Amin S and Rahman S (2010) "Application on Electronic Banking in Bangladesh; An Overview." Bangladesh Research Publications Journal.

[2] Auta M M (2010) "E-banking in Developing Economy: Empirical Evidence from Nigeria" Journal of Applied Quantitative Methods.

[3] Baten M A and Kamil A A (2010) "E-Banking of Economical Prospects in Bangladesh." Journal of Internet Banking and Commerce.

[4] Huda F and Ahmed T (2017) "Prospect of E-Banking in Bangladesh: New Way to Make Banking Electronic." Asian Economic and Financial Review.

[5] Rahman M, Saha N K, Sarkaer M N I, Sultana A and Prodhan A Z M S (2017) "Problems and Prospects of Electronic Banking in Bangladesh: A Case Study on Dutch-Bangla Bank Limited" American Journal of Operations Management and Information Systems.

[6] Ahmed S M S, Rayhan S J, Islam M A (2011) "Problems and Prospects of Mobile Banking in Bangladesh." Journal of Information Engineering and Applications.

[7] Sharafi M A A, Arshah R A, Herzallah F A T and Shanab E A A (2018) "The impact of Customer Trust and Perception of Security and Privacy on the Acceptance of Online Banking Services: Structural Equation Modeling Approach." International Journal of Industrial Management (IJIM).

[8] Moga L M, Neculita M, \& Khani N (2012) “Trust and 
Security in E-banking Adoption in Romania." http://rc4ht3qs8p.search.serialssolutions.com

[9] Mohiuddin U (2014) "Trend and Development of E-Banking: A Study on Bangladesh." IOSR Journal of Business and Management.

[10] Nasri W (2011) "Factors Influencing the Adoption of Internet Banking in Tunisia" International Journal of Business and Management.

[11] Riyadh A N, Akter M S and Islam N (2009) "The Adoption of E-banking in Developing Countries: A Theoretical Model for SMEs. "International Review of Business Research Papers.

[12] Sudeep S (2007) "Internet Banking and Customer Acceptance: The Indian Scenario" Doctor of Philosophy, Dept of Applied Economics, Cochin University of Science \& Technology.

[13] Gunaratnam A, Konalingam K, Ratnam U \& Sivapalan A (2018) "Factors Influencing on E-Banking Practices: Evidence from Sri Lanka." Journal of Sociological Research.
[14] Shergill G H \& Li B (2005) "An Empirical Investigation of Customers' Behavior for Online Banking in New Zealand." Journal of Internet Commerce.

[15] Sadekin M S \& Shaikh M A H (2016) "Effect of E-Banking on Banking Sector of Bangladesh." International Journal of Economics, Finance and Management Sciences.

[16] Skvarciany V and Jureviciene D (2018) "Factors Influencing Individual Customers Trust in Internet Banking: Case of Baltic States" Sustainability 2018, 10, 4809; doi: 10.3390/su10124809.

[17] Suh B and Han I (2002) "Effect of trust on customer acceptance of Internet banking." Electronic Commerce Research and Applications Volume 1, Issues 3-4.

[18] Anguelov, Christoslav E, Marianne A H, and Jeanne M H (2004) "U.S. Consumers and Electronic Banking, 1995-2003." Federal Reserve Bulletin, 90 (Winter): 1-18. B. 